\title{
PUBLIC POLICIES FOR POST-GRADUATION: EXPANSION AND CHALLENGES FOR THE PROFESSIONAL MASTER IN BRAZIL
}

\begin{tabular}{c}
\hline POLÍTICAS PÚBLICAS PARA A PÓS-GRADUAÇÃO: \\
EXPANSÃO E DESAFIOS PARA O MESTRADO PROFISSIONAL NO BRASIL \\
POLÍTICAS PÚBLICAS PARA POSTGRADO: \\
EXPANSIÓN Y DESAFÍOS PARA MAESTROS PROFESIONALES EN BRASIL
\end{tabular}

\section{Adilene Gonçalves Quaresmai}

\begin{abstract}
The text presents an analysis and discussion of data about the expansion of professional masters in Brazil in recent years and the challenges that this expansion presents for Brazilian stricto sensu post-graduate programs. The data were collected based on the site of the Sucupira Platform on February 14, 2017, as part of the research entitled Pedagogical Issues of the Professional Master's Degree, developed in the Professional Master in Social Management, Education and Local Development of UNA. This text is structured around two central axes: the first discusses the Educational Policies for stricto sensu post-graduation and the expansion of the Professional Master's Programs, as well as its effects for the expansion of the professional masters; and the second presents the methodological procedures, analysis and discussion of the data. Among the conclusions, it is highlighted that the expansion of the professional master's degree has been higher in the Southeast region of Brazil and led by public institutions. Another important aspect of this expansion is the diversity of courses, which demonstrates the concern of the offering institutions with the local and regional socioeconomic and cultural demands, as well as attention to the characteristics of the professional master's degree.
\end{abstract}

KEYWORDS: Educational policies. Stricto sensu post-graduation. Professional master. Brazil.

RESUMO: O texto apresenta análise e discussão de dados sobre a expansão do mestrado profissional no Brasil nos últimos anos e os desafios que essa expansão representa para a pós-graduação stricto sensu brasileira. Os dados foram levantados com base no site da Plataforma Sucupira em 14 de fevereiro de 2017, como parte da pesquisa intitulada Questões Pedagógicas do Mestrado Profissional, desenvolvida no Mestrado Profissional em Gestão Social, Educação e Desenvolvimento Local, do Centro Universitário UNA. O texto estrutura-se em torno de dois eixos centrais. O primeiro: Políticas Educacionais para pós-graduação stricto sensu e a expansão dos Mestrados Profissionais, no qual se discute a política pública para a pós-graduação e seus efeitos para a expansão dos mestrados profissionais; e o segundo que apresenta os procedimentos metodológicos, análise e discussão dos dados. Os resultados indicam que a expansão do mestrado profissional tem sido maior na região sudeste e liderada pelas instituições públicas. Outro aspecto relevante nessa expansão é a diversidade de cursos, o que demonstra preocupação das instituições ofertantes com as demandas socioeconômicas e culturais locais e regionais, bem como atenção às características do mestrado profissional.

PALAVRAS-ChAVE: Política educacional. Pós-graduação stricto sensu. Mestrado profissional. Brasil.

RESUMEN: El artículo presenta el análisis de datos y discusión de la expansión de la maestría profesional en Brasil en los últimos años y los retos que esta expansión ofrece para el estricto sensu graduado de Brasil. Se recogieron los datos basados en el sitio Plataforma Sucupira el 14 de febrero de 2017, como parte de la investigación titulada pedagógicos preguntas maestría profesional, desarrollada en el Master Profesional en Gestión Social, Educación y Desarrollo Local, Universidad Centro de la UNA. El texto está estructurado en

Submitted: 13/04/2017 - Accept: 21/06/2017 - Published: 08/08/2017.

\begin{tabular}{l|c|c|c|c|c} 
(C) Rev. Inter. Educ. Sup. & Campinas, SP & v.3 & n.3 & p.706-718 & set./dez. 2017 \\
\hline
\end{tabular}


torno a dos ejes centrales. Los primeros: Políticas educativas a un estricto post-graduación y la expansión del Maestro profesionales, que analiza las políticas públicas para el graduado y sus efectos sobre la expansión de grados de maestría profesional; y el segundo que tiene los procedimientos metodológicos, análisis y discusión de los datos. Entre las conclusiones, se destaca que la expansión de la maestría profesional ha sido mayor en la región Sudeste y dirigido por las instituciones públicas. Otro aspecto importante de esta expansión es la diversidad de cursos, que muestra preocupación por las instituciones que ofrecen a las exigencias locales y regionales socioeconómicos y culturales, así como la atención a las características de la maestría profesional.

PALABRAS ClAVE: Política educativa. Los estudios de post-grado. Maestros profesionales. Brasil

\section{INTRODUCTION}

A public policy comprises a set of guidelines for the implementation, by the government, of the demands placed by society. In this process, relationships between public power and society are not harmonious; they comprise conflicts and disputes, since the groups that make up the society are distinct and have different interests. Thus, educational policies also take into consideration such issues and, in Brazil, they have been consolidated in a context of divergences, disputes, and the search for consensus.

The Educational Policy for Higher Education in Brazil, since 2002, has presented several strategies to meet the demands for economic and social development from the current socioeconomic context and for increasing the population's access to this level of education. Educational Policies and Programs will be directed to both undergraduate and postgraduate courses, and in postgraduate studies the professional master's degree has undergone significant expansion in recent years in private and public education institutions. Another important element in this expansion process is the concern with professional development and with the demands of the world of work, since these criteria have been considered in the creation of courses.

In this sense, the discussion presented here is part of the analysis of quantitative data on the professional master in Brazil, based on the site of the Platform Sucupira on February 14 , 2017.

This text is structured around two central axes: the first discusses the Educational Policies for stricto sensu post-graduation and the expansion of the Professional Master's Programs, as well as its effects for the expansion of the professional masters; and the second presents the methodological procedures, analysis and discussion of the data. In the presentation of the methodological procedures, were defined two categories of analysis: number of courses, and administrative dependence of the institutions. 


\section{EDUCATIONAL POLICIES FOR hIGHER EDUCATION: PROFESSIONAL MASTER'S AND STRICTO SENSU POST-GRADUATE PROGRAMS}

As for the Educational Policy for Postgraduate Programs, according to Ramos (n.d.), the Planos Nacionais de Pós-graduação [Brazilian National Postgraduate Plans] played a fundamental role in the process of institutionalization of the Brazilian Postgraduate, though other educational policies also have constituted means to stimulate this level of education. For the author, the Law 9,394, the Lei de Diretrizes e Bases da Educação [Law of Guidelines and Bases of Education] - LDB, approved in December 1996, in its Art.52, in paragraphs II and III, determines that at least one-third of the university's teaching body must be constituted by professional with stricto sensu Post-graduation and one-third of them must work on a fulltime basis. This forced the investment in the creation of stricto sensu postgraduate courses, their valorization, and also ensured conditions for greater participation of faculty in research activities, due to the full-time regime. According to the same author, the Brazilian Constitution also ensures, through its Article 218, paragraph 3, that "the State shall support the formation of human resources in the areas of science, research and technology and shall grant to those who are concerned, means and special conditions of work "(RAMOS, n.d.) ${ }^{2}$.

But since 1965, the Brazilian postgraduate programs have been structured with Report No. 977 CES / CFE, dated December 3, 1965, known as the Parecer Sucupira [Sucupira's Report], and the University Reform of 1968, that is, according to Alves and Oliveira (2014, p. 352):

The purpose was to implement and develop the postgraduate courses regime in higher education, since it was understood that there was a lack of precision regarding the nature of postgraduate courses in the country. It is in this context of the Military Regime that the postgraduate has undergone a movement of structuring, normalization and institutionalization, as well as of expansion of the promotion, expansion and adoption of evaluation systematic, whose guidelines and bases still remain today.

Still according to Alves and Oliveira (2014, p.360), for some authors the postgraduate degree would be a legacy of the Military Dictatorship that implemented it as a strategy to consolidate "the University Reform, highlighting the perspective of the formation of high level staff, the research and development of the sciences, especially in terms of new technologies and applied knowledge for the country's economic growth."

Once structured by the Military Regime, the Brazilian graduate followed the American model, because at the time the relations between Brazil and the US were close through the

\footnotetext{
${ }^{2}$ All the bibliographic quotations were translated freely from Portuguese to English by the author of the present study.
} 
MEC / USAID agreements and for the postgraduate studies the Atcon Report of 1966 was significant.

According to Savianni (2008, p.310), Brazilian postgraduate students had a double influence "[...] of the American organizational model that was articulated in the effective functioning of the training process, being the European model guided by the requirement of autonomously conducted theoretical work [...]".

Without examining the real interests of the military when they implemented post-graduation in Brazil, the fact is that this education level is a place for scientific and technological production and which is currently consolidated and able to compete with other countries of the world, for example, from North America and Europe.

Throughout its history, Brazilian postgraduate programs, besides the Coordenação de Aperfeiçoamento de Pessoal de Nível [Superior Coordination of Improvement of Higher Level Personnel] - CAPES, founded in 1951, charged with a fundamental role in the expansion and consolidation of the stricto sensu postgraduate, and Conselho Nacional de Desenvolvimento Científico e Tecnológico [National Council for Scientific and Technological Development] - CNPq, also created in 1951, with the objective of stimulating the development of scientific and technological research of Brazilian universities, have had five National Postgraduate Plans that guide, plan and set goals for the post -graduation every 10 years, namely: I PNPG (1975-1979); II PNPG (1982-1985); III PNPG (1986-1989); IV PNPG (2005-2010); V PNPG 2011-2020.

The analysis of the data from these plans shows that throughout its existence the Brazilian postgraduate program has grown. The 2011-2020 PNPG also reveals that Brazilian postgraduation continues to grow, but at a slower pace than in 2010 (PNPG, 2011-2020)

Table 1. Recommended and recognized programs and courses

\begin{tabular}{|c|c|c|c|c|c|c|c|c|c|}
\hline & \multicolumn{5}{|c|}{ Total Graduate Programs } & \multicolumn{3}{|c|}{$\begin{array}{l}\text { Postgraduate } \\
\text { Totals }\end{array}$} & \multirow{2}{*}{$\begin{array}{r}\text { Course } \\
\mathrm{MF}\end{array}$} \\
\hline Region & Total & ME & DO & MF & ME/DO & Total & ME & DO & \\
\hline MIDWEST & 358 & 143 & 9 & 52 & 154 & 506 & 295 & 161 & 50 \\
\hline NORTHEAST & 890 & 399 & 17 & 148 & 326 & 1200 & 719 & 340 & 141 \\
\hline NORTH & 246 & 116 & 4 & 48 & 78 & 321 & 192 & 82 & 47 \\
\hline SOUTHEAST & 1956 & 409 & 42 & 386 & 1119 & 3053 & 1520 & 1156 & 377 \\
\hline SOUTH & 938 & 310 & 11 & 157 & 460 & 1382 & 760 & 468 & 154 \\
\hline Totals & 4388 & 1377 & 83 & 791 & 2137 & 6462 & 3486 & $\overline{2207}$ & 769 \\
\hline
\end{tabular}

Subtitle ME: Academic Master's Degree DO: PhD MB: Professional Master's Degree ME / DO: Master's and Doctoral Degree

\begin{tabular}{|l|l|l|l|l|l|} 
(C) Rev. Inter. Educ. Sup. & Campinas, SP & v.3 & n.3 & p.706-718 & set./dez. 2017 \\
\hline
\end{tabular}


Table 1 above shows the numbers of recognized and recommended programs ${ }^{3}$. In May 2014 there were 5,670 courses among masters and doctoral ones; in February 2017 this number was 6,462, with 3,486 academic masters, 2,207 doctorates and 769 professional masters. A significant growth can be se observed over the last almost three years.

However, more than the numbers, it is also important to consider the meaning of the Brazilian postgraduate courses for the scientific and technological development of the country, as well as for the labor market and society in general. In this sense, one of the necessary actions is the expansion of the programs across the Brazilian territory beyond the Southeast and South regions, in which the programs have been concentrated.

For Gazzola and Fenati (2010), in order for Brazilian graduate students to respond more adequately to the needs of the country, it is necessary an expansion in strategic points of the Brazilian territory. Another aspect, pointed out by these theorists, that we must also take into consideration, is internationalization, already in course, though it needs to be strengthened through actions that include syndicated programs focusing on common characteristics and problems.

That is to say, the discussions and studies held in Capes, CNPq, universities, specific forums, and the National Postgraduate Plans have all contributed to create actions for the expansion and improvement of the Brazilian postgraduate. The Professional Master's Degree is then prioritized in view of the purpose of the article.

Regarding the professional master's degree, Report $n^{\circ}$ 80, of December 16, 1998, which formalizes and regulates the course, guaranteeing the degree with the same prerogatives of the academic master's degree, was an important landmark; The Para além da Academia [Beyond the Academy] seminar, organized by the Foundation's management on the campus of Universidade Federal de São Paulo [Federal University of São Paulo] (UNIFESP), in April 2005 was another significant event; and another important initiative came from the coordinators of the Professional Master's courses, who made the first meeting in May 2006 in São Paulo and the second edition in early November in the city of Campo Grande, in the state of Matogrosso do Sul, with more than 40 participants (AGOPYAN, LOBO, 2007). That is to say, they were important actions for the implementation of professional masters and "the idea of Professional Master's degree is already consolidated, with courses established with great

\footnotetext{
${ }^{3}$ On Friday, March 24, 2017, Ministerial Order No. 389, dated March 23, 2017, of the Ministry of Education was published in the Official Gazette of the Union (DOU), which establishes, within the scope of the stricto postgraduate course Sensu, the modality of professional doctorate, hitherto not existing in the National Graduate System.
} 
repercussion and recognition in most areas of knowledge, throughout the Country" (AGOPYAN, LOBO, 2007, 295). There are 791 programs located in all Brazilian regions.

The professional master's degree became from then on a stricto sensu postgraduate course, instituted by CAPES, through Report No. 47, dated October 17, 1995.

The professional master's degrees have been developed in the Brazilian post-graduation from the 1960s, after the promulgation of LDB. In 1965, with Report No. 977/65, produced by Professor Newton Sucupira, it began at Brazil the distinction between the nature and purposes of post-graduation courses, leading to the regulation of B subparagraph of Art. 69 of the referred law and to the organization of the expansion of these courses.

The central elements in the professional master's degree are its potential for educating teachers theoretically and technically for the professional performance and the promotion of the development and induction of the emergence of new professional activities that meet the demands of the academic and non-academic sectors of each locality. The professional master's degree, from this perspective, requires an integration of theoretical education with the demands of the world of work, as well as with the innovation needs placed by current social and economic development.

Another important issue is the validity of the professional master's degree with emphasis on the qualification process for the performance in social institutions. According to Feltes and Baltar (2005, p.74), "the qualification of the professionals who work in different areas of knowledge is both a marketing and social demand in a broad sense".

According to Negret (2008), the data from CAPES, in April 2008, indicated that 225 professional masters were accredited. The review for this research in 2014 indicated 581 courses, which corresponds to an increase of more than $100 \%$ in five years, and in 2017 indicated 769 courses, that is to say, in almost three years there was again a significant increase of courses. Besides the growth in numbers, according to Giuliani (2010, p. 99), "the professional master's degree has been appearing in areas of the most different natures", and its emphasis is on vocational training.

The courses have a minimum duration of 1 and a maximum of 2 years, and, if necessary, the student can complete, as in the academic postgraduate program, up to a maximum of 30 months, that is, $2 \frac{1}{2}$ years. They have been offered both in full in-person and online format with in-person support. In the private institutions the financing is with the payment of enrollments by the students. In the public institution, there is no monthly fee, but: "It is possible, however, to 'sell' courses to companies for the training of their employees, provided that the student selection process is public (PNPG 2011-2020 - BRASIL, 2010, p.306). 


\section{METHODOLOGICAL PROCEDURES, DOCUMENTAL RESEARCH, DATA ANALYSIS AND DISCUSSION}

The data were collected based on the CAPES website ${ }^{4}$, with access on February $14^{\text {th }}, 2017$. For the analysis, we first considered the number of programs and courses per region. Then, programs/course were counted and tabulated, one by one, from each state by region. Then each link from each of the institutions was opened to verify the administrative dependency only in the Southeast region. The categories of analysis defined were: quantity of program/course by region and state; administrative dependence of the institutions of the southeast region and of Minas Gerais, and challenges and issues that the data point to.

Number of Professional Master's programs / courses in Brazil by region

The Table 2, the Southeast Region has the highest number of programs/courses, with $48.79 \%$; followed by the South region, with $19.84 \%$; and the Northeastern region, with $18.71 \%$. In the Northeast, there is a significant presence of courses, almost equal to the number of the South. These data have aroused a few questions: What is provoking expansion in the Southeast, South and Northeast? Why do the north and center-west regions show less growth?

Table 2. Program / course (s) by Brazilian region by quantity and percentage

\begin{tabular}{l|r|r}
\hline Region & Quantity & \multicolumn{2}{|c}{$\%$} \\
\hline MIDWEST & 52 & 6,57 \\
NORTHEAST & 148 & 18,71 \\
NORTH & 48 & 6,06 \\
SOUTHEAST & 386 & 48,79 \\
SOUTH & 157 & 19,84 \\
\hline BRAZIL & $\mathbf{7 9 1}$ & $\mathbf{1 0 0}$ \\
\hline
\end{tabular}

Source: Data organized by the author based on the Capes website -14.02 .2017$

The expansion of the professional master's degree aims at meeting a demand from business, academy and society in general for better qualification of professionals in the various areas, in view of improving the quality of the services offered, as well as contributing to the development of specific areas, localities, products, services, strategies and methodologies, considering the diversity of areas/courses in which the professional masters are created.

\footnotetext{
${ }^{4}$ Os dados foram coletados no dia 14 de fevereiro de 2017 no site da Plataforma Sucupira e não constava a data da última atualização como constava no site anterior da Capes de 2015, quando no dia 21.07.15 fiz um levantamento e constava a última atualização em 20.03.2015. Sendo assim, considera-se a data da coleta como referência. Disponível em <https://sucupira.capes.gov.br/sucupira/> Ultimo acesso em 12/07/2015.
} 
The expansion of higher education in Brazil, in general, has always occurred from the Southeast region and in the following order, similar to what happens to the expansion of the professional master's degree, that is, first the Southeast, then South and Northeast regions, with little expansion in the North and Midwest. This situation leads to the conclusion that the expansion of the professional master's degree follows the same tendency of the expansion of higher education in relation to the regions and also considers the economic development a little larger of these regions.

Number of programs / courses by states of the Brazilian regions

In the northern region, Pará is the state with more Professional Masters courses, accounting for $50 \%$ of them. Amazonas has $18.75 \%$ and Tocantins, $12.50 \%$. In this region, it was Pará that started the process of insertion in its teaching institutions of Professional Master Programs, with a greater number of them at Universidade Federal do Pará [Federal University of Pará] UFPA (Table 3).

Table 3. Programs/courses in the Northern region by state

\begin{tabular}{l|r|r}
\hline \multicolumn{1}{c|}{ State } & Quantity & \% \\
\hline Acre & 1 & 2,08 \\
Amazonas & 9 & 18,75 \\
Amapá & 1 & 2,08 \\
Pará & 24 & 50 \\
Rondônia & 4 & 8,33 \\
Roraíma & 3 & 6,25 \\
Tocantins & 6 & 12,50 \\
Totals & $\mathbf{4 8}$ & $\mathbf{1 0 0}$ \\
\hline
\end{tabular}

Source: Data organized by the author based on the Capes website - 14.02.2017

In the northeast region (Table 4), the state of Pernambuco has the largest number of professional master's degrees, accounting for $22.29 \%$ of the courses. Then it comes the state of Bahia with 21.62\%, and the states of Ceará with 18.24, and Rio Grande do Norte with $14.86 \%$. We could ask ourselves, what reasons determine the greater presence of courses in the states of Pernambuco, Bahia, Ceará and Rio Grande do Norte and much smaller amounts in the other states of the northeast region?

Table 4. Programs / Courses in the Northeast Region by State

\begin{tabular}{|c|c|c|c|c|c|}
\hline State & Quanti & & $\%$ & & \\
\hline Alagoas & & 8 & 5,40 & & \\
\hline Bahia & & 32 & 21,62 & & \\
\hline Ceará & & 27 & 18,24 & & \\
\hline Maranhão & & 6 & 4,05 & & \\
\hline Paraíba & & 12 & 8,10 & & \\
\hline Pernambuco & & 33 & 22,29 & & \\
\hline (C) Rev. Inter. Educ. Sup. & Campinas, SP & v.3 & n.3 & p.706-718 & set./dez. 2017 \\
\hline
\end{tabular}




\begin{tabular}{l|r|r} 
Piauí & 5 & 3,37 \\
Rio Grande do Norte & 22 & 14,86 \\
Sergipe & 3 & 2,02 \\
Totals & $\mathbf{1 4 8}$ & $\mathbf{1 0 0}$ \\
\hline
\end{tabular}

Source: Data organized by the author based on the Capes website - 14.02.2017

It is important to note that in the last survey conducted in March 2014 in this region, the state of Bahia had a greater number of Programs, followed by the state of Pernambuco. There was also a significant increase in courses in the states of Ceará and Rio Grande do Norte.

In the Midwest (Table 5), the Federal District has the largest number of courses, with 40.38\%; followed by Goiás, with $36.53 \%$. It is noteworthy the smaller number of courses in Mato Grosso, well below the other states.

Table 5. Programs / courses in the Midwest by state

\begin{tabular}{l|r|r}
\hline State & Quantity & \multicolumn{1}{|c}{$\%$} \\
\hline Distrito Federal & 21 & 40,38 \\
Goiás & 19 & 36,53 \\
Mato Grosso do Sul & 9 & 17,30 \\
Mato Grosso & 3 & 5,76 \\
\hline Totals & $\mathbf{5 2}$ & $\mathbf{1 0 0}$ \\
\hline
\end{tabular}

Source: Data organized by the author based on the Capes website - 14.02.2017

In the Southeast (Table 6), the state with the largest number of courses is São Paulo, with 41.70\%; followed by Rio de Janeiro, with 33.16\%. What factors are influencing this expansion in each state? What explains the significant difference between the figures of Espírito Santo with $4.66 \%$ and São Paulo with $41.70 \%$ ?

One of the explanations for these questions is that São Paulo and Rio de Janeiro, besides having more institutions of higher education, are states with a higher level of economic development than Espírito Santo and Minas Gerais, which may explain a greater demand that would lead to a growth in supply.

Table 6. Programs / Courses in the Southeast Region by State

\begin{tabular}{l|l|r}
\hline State & Quantity & \% \\
\hline Espírito Santo & 18 & 4,66 \\
Minas Gerais & 79 & 20,46 \\
Rio de Janeiro & 128 & 33,16 \\
São Paulo & 161 & 41,70 \\
\hline Totals & $\mathbf{3 8 6}$ & $\mathbf{1 0 0}$ \\
\hline
\end{tabular}

Source: Data organized by the author based on the Capes website - 14.02.2017

In the southern region (Table 7), there is a presence of $48.40 \%$ of the courses in the state of Rio Grande do Sul, almost 50\%, and a distribution of the other $50 \%$ balanced in the states of 
Paraná with $24.84 \%$ and Santa Catarina with 26, 75\%. What determines this great presence of professional master's degrees in Rio Grande do Sul? The hypotheses for significant expansion in the South and Southeast regions are that these regions are, historically, regions of greater economic development and with a strong presence of public and private higher education institutions.

Table 7. Programs / courses in the southern region by state - 2015

\begin{tabular}{l|r|r}
\hline State & Quantity & \% \\
\hline Paraná & 39 & 24,84 \\
Rio Grande do Sul & 76 & 48,40 \\
Santa Catarina & 42 & 26,75 \\
\hline Totals & $\mathbf{1 5 7}$ & $\mathbf{1 0 0}$ \\
\hline
\end{tabular}

Source: Data organized by the author based on the Capes website - 14.02.2017

The data above demonstrate that in each region there are one or two states that present a greater number of Programs while others have a number far below these. The states with the highest number of Programs, in some regions, are states with better economic performance and greater presence of public and private higher education institutions.

The data allow us to state that the Southeast region is the one with the largest number of Programs, followed by the South Region, which is related to the strong economic potential and the higher concentration of higher education institutions in these regions in relation to the others.

Number of programs/courses per administrative unit in the southeast region

We present here the distribution of the Programs in view of the administrative dependence of the institutions of the southeast region in order to have a broader understanding of this distribution. Accordingly, Table 8 below shows that in the Southeast, 52.33\% of the Programs are in private institutions, and $47.66 \%$ in public institutions. The state with the highest presence of courses in private institutions is São Paulo, with $56.93 \%$ and Rio de Janeiro with $29.70 \%$.

In relation to the Programs in public institutions, there are $47.66 \%$ and it is the state of Rio de Janeiro that contains the largest number, $36.95 \%$, followed by the state of Minas Gerais with $30.97 \%$.

Table 8. Programs / Courses in the Southeast Region by Administrative Dependence

\begin{tabular}{l|l|l|l|l|l|r}
\hline State & Private & \% & Public & \% & \\
\hline Espírito Santo & 5 & & 2,47 & 13 & 7,06 \\
Minas Gerais & \multicolumn{2}{|l|}{10,89} & 57 & 30,97 \\
\hline ○ Rev. Inter. Educ. Sup. & Campinas, SP & v.3 & n.3 & p.706-718 & set./dez. 2017 \\
\hline
\end{tabular}




\begin{tabular}{l|r|r|r|r} 
Rio de Janeiro & 60 & 29,70 & 68 & 36,95 \\
São Paulo & 115 & 56,93 & 46 & 25 \\
\hline Total & $\mathbf{2 0 2}$ & $\mathbf{5 2 , 3 3}$ & $\mathbf{1 8 4}$ & $\mathbf{4 7 , 6 6}$ \\
\hline
\end{tabular}

Source: Data organized by the author based on the Capes website - 14.02.2017

Comparing the survey carried out in 2014 and the one carried out now in 2017, for the southeast region, we can affirm that the Professional Master Programs have grown considerably in private and public institutions, and that the differences in quantity, among them, are not very expressive.

In this sense, we can affirm that, unlike the first years of the professional masters, in which there was a tendency and an understanding that they would be prerogatives only of private institutions, are now consolidated in the Brazilian postgraduate and in the two modalities of Administrative dependency, that is, public and private.

\section{CONSIDERATIONS ON SUBMITTED DATA}

The Brazilian stricto sensu Post-graduation is consolidated both in academic and professional modalities. Despite the challenge of expanding to regions with little presence and internationalization, the current scenario, considering the social, economic, political and regional difficulties of Brazil, is not so bad in view of what is already consolidated in relation to the quantity and quality of public and private programs. What is worrying is the political and economic crisis in which the country is located, which has led to the cut of funds for public universities, as well as for the scholarships and research funding, and it also aggravates the conditions of the Programs in private institutions.

With regard to professional masters, the results show a significant expansion in recent years in both private and public institutions. The Southeast region has the largest number of courses, followed by the South and Northeast. The expansion of the professional masters in the Southeast and South regions can be explained by the greater presence of public and private institutions, as well as by the historical economic development of these regions, which is relatively higher than in the North, Northeast and Central West regions.

As for the administrative dependence of the institutions, we can observe a greater presence of courses in public institutions. This fact is interesting, since it reveals that, contrary to the initial period of creation of the courses, they grew in public institutions, mainly in the federal ones, which takes away the idea that the professional master's degree is prerogative of particular institutions and shows that in the last few years, federal governments, through CAPES and CNPq, have adopted a policy of encouraging and recognizing professional masters in public institutions. This policy, on the one hand, is articulated to the new

n. 3

p.706-718

set./dez. 2017 
restructuring of professional education; on the other hand, it meets the labor market demand with which the professional master's degree is related more closely than the academic one.

The contribution of this article was to demonstrate the expansion of professional masters and to point out some issues that this expansion has placed. It remains, therefore, to explore further data and to initiate new research on professional master's degrees in Brazil.

\section{REFERENCES}

AGOPYAN, Vahan; LOBO, Roberto. O futuro do mestrado profissional. RBPG, Brasília, DF, v. 4, n. 8, p. 293-302, dez., 2007. Disponível em: <http://ojs.rbpg.capes.gov.br/ index.php/rbpg/article/view/138>. Acesso em: 14 de maio de 2015.

ALVES, Miriam Fábia; OLIVEIRA, João Ferreira de. Pós-Graduação no Brasil: do Regime Militar aos dias atuais. RBPAE, v. 30, n. 2, p. 351-376, mai/ago. 2014. Disponível em: https://pt.scribd.com/document/258215420/pos-graduacao-da-ditadura-a-te-os-dias-atuaispdf>. Acesso em: 08 de janeiro de 2017.

BRASIL. Ministério da Educação. Coordenação de Pessoal de Nível Superior - CAPES. Plano Nacional de Pós-Graduação - PNPG 2011-2020. Brasília, DF: CAPES, 2010. Disponível em: 〈https://www.capes.gov.br/images/stories/download/PNPG_Miolo_V2.pdf > . Acesso em: 08 jan. 2017.

BRASIL. Ministério da Educação. Coordenação de Pessoal de Nível Superior - CAPES. Portaria no 47, de 17 de outubro de 1995. RBPG, Brasília, DF, v. 2, n. 4, p. 147-148, jul. 2005.

Disponível em: <http://ojs.rbpg.capes.gov.br/index.php/rbpg/article/view/87/83>. Acesso em 3 de julho de 2015.

FELTES, Heloisa Pedroso de Moraes; BALTAR, Marcos Antonio Rocha. Novas perspectivas para mestrados profissionais: competências profissionais e mercados regionais. RBPG, v. 2, n. 4, p. 72-78, jul., 2005. Disponível em: <http://ojs.rbpg.capes.gov.br/ index.php/rbpg/article/download/79/76>. Acesso em: 13 de março de 2014.

GAZZOLA, Ana Lúcia Almeida; FENATI, Ricardo. A Pós-Graduação Brasileira no Horizonte de 2020. In: BRASIL, Ministério da Educação. Coordenação de Pessoal de Nível Superior - CAPES. Plano Nacional de Pós-Graduação - PNPG 2011-2020. Brasília, DF: CAPES, 2010. p.7-16. Disponível em: 〈https://www.capes.gov.br/images/stories/ download/PNPG_Miolo_V2.pdf>. Acesso em: 12 de dezembro de 2016.

GIULIANI, Antonio Carlos. Perfil profissiográfico dos egressos do Programa de Mestrado Profissional em Administração de uma instituição de ensino do interior do Estado de São Paulo. Rev. Adm. UFSM, Santa Maria, v. 3, n.1, p. 94-108, jan./abr., 2010. Disponível em: <https://periodicos.ufsm.br/reaufsm/article/view/2242>. Acesso em 05 de junho de 2015. 
NEGRET, Fernando. A identidade e a importância dos mestrados profissionais no Brasil e algumas considerações para a sua avaliação. RBPG, Brasília, DF, v. 5, n. 10, p. 217-225, dez., 2008. Disponível em: 〈http://ojs.rbpg.capes.gov.br/index.php/rbpg/article/view/152〉. Acesso em 05 de junho de 2015.

RAMOS, M. da G. Expansão e pós-graduação stricto sensu captando desafios.

GEUIpesq/UFPel. Disponível em: 〈http://www.portalanpedsul.com.br/>. Acesso em: 4 jan. 2015.

SAVIANI, Dermerval. O legado educacional do Regime Militar. Cadernos Cedes. Campinas, SP, v.28, n.76, set./dez.2008. Disponível em: <http://www.scielo. br/pdf/ccedes/v28n76/ a02v2876.pdf>. Acesso em 12 dez.2016.

\section{${ }^{\mathrm{i}}$ Sobre a autora}

\section{Adilene Gonçalves Quaresma}

E-mail: adilenequaresma@gmail.com / ORCID: http://orcid.org/0000-0002-7344-8610

Centro Universitário Una - Brasil

Doutora em Educação pela Faculdade de Educação da Universidade Federal de Minas Gerais [UFMG] 